\title{
PENGARUH PEMASARAN RELASIONAL, KEPERCAYAAN, KEDEKATAN EMOSIONAL TERHADAP LOYALITAS PELANGGAN (Studi kasus BOLT 4G LTE)
}

\author{
Rendy Ahmaediansyah \\ E-mail : rendybc5@gmail.com \\ Yulia Nurendah \\ lianiceone@yahoo.com
}

\begin{abstract}
ABSTRAK
Perkembangan bisnis di bidang telekomunikasi sudah semakin berkembang dan perusahaan perusahaan di bidang ini semakin gencar dalam melakukan persaingan untuk mendapatkan konsumen yang loyal. Namun adapun permasalahan dari persaingan ini seperti berpindahnya konsumen dari produk satu ke produk yang lain karena perusahaan kurang memperhatikan konsumen terlebih lagi tidak adanya kedekatan antara konsumen dengan perusahaan.

Penelitian ini bertujuan : 1). Untuk mengetahui apakah pemasaran relasional, kepercayaan, dan kedekatan emosional secara bersama mempunyai pengaruh signifikan terhadap loyalitas pelanggan pada perusahaan BOLT 4G LTE ; 2). Untuk mengetahui apakah pemasaran relasional berpengaruh terhadap loyalitas pelanggan ; 3). Untuk mengetahui apakah kepercayaan berpengaruh terhadap loyalitas pelanggan ; 4). Untuk mengetahui apakah kedekatan emosional berpengaruh terhadap loyalitas pelanggan.

Analisis yang digunakan dalam penelitian ini adalah analisis regresi linear berganda, pemilihan sampel dilakukan dengan cara purposive sampling. Adapun sampel yang digunakan berjumlah 100 responden, dengan analisis regresi linear berganda. Penelitian ini mempergunakan metode Rosque.

Hasil penelitian menunjukkan 1). Pemasaran relasional, kepercayaan, kedekatan emosional secara bersama-sama mempunyai pengaruh positif dan signifikan terdahap loyalitas pelanggan ; 2). Pemasaran relasional berpengaruh positif dan signifikan terhadap loyalitas pelanggan ; 3). Kepercayaan berpengaruh positif dan signifikan terhadap loyalitas pelanggan ; 4). Kedekatan emosional berpengaruh positif dan signifikan terhadap loyalitas pelanggan. Hasil analisis menggunakan koefisien determinasi diketahui bahwa $76 \%$ variabel loyalitas pelanggan dapat dijelaskan oleh variasi dari variabel pemasaran relasional, kepercayaan dan kedekatan emosional, sedangkan $24 \%$ dijelaskan oleh variabel lain yang tidak terdapat dalam penelitian ini.
\end{abstract}

Kata kunci: Pemasaran Relasional, Kepercayaan, Kedekatan Emosional, Loyalitas pelanggan.

\section{PENDAHULUAN}

Dalam perkembangannya, teknologi telekomunikasi mulai menjadi hal yang sangat penting, karena teknologi ini meningkatkan keefektifan manusia untuk berhubungan dalam jarak yang sangat jauh sekalipun. Sampai sekarang, kebutuhan manusia akan teknologi ini masih sangat tinggi. Kompetisi bisnis telekomunikasi pada penyedia jasa layanan internet di Indonesia tampak semakin intens sebagai akibat dari ekspansi yang dilaksanakan oleh pemain provider lama seperti Telkomsel, Indosat,
$\mathrm{XL}$ dan adanya pemain operator baru seperti Natrindo, Hutchison, dan Internux. Persaingan kualitas produk dan harga begitu pesat, menuntut para pemasar untuk dapat menyediakan produk-produk yang berkualitas dan harga yang terjangkau oleh konsumen serta dapat mengembangkan suatu produk yang bermanfaat dan inovatif sesuai dengan harapan konsumen dan kebutuhan pasar, sehingga kepuasan setelah mengkonsumsi dapat diperoleh dan akan membuat konsumen melakukan pembelian dimasa yang akan datang atau pembelian berulang pada produk yang 
sama. Produsen berlomba-lomba dapat bersaing dengan kompetitor. Hal ini dapat dilihat dari semakin banyaknya perusahaan yang menghasilkan produk dengan jenis dan kegunaan yang sama akan tetapi berbeda harga, fitur produk, dan layanan. Konsumen pun bersikap lebih selektif dan kritis dalam memilih produk yang akan dibeli. Konsumen tidak lagi membeli produk sekedar berdasarkan pertimbangan wujud fisik saja, namun juga termasuk segala aspek pelayanan yang melekat pada produk, mulai dari tahap pembelian sampai pada tahap pasca pembelian (supardi, 2009).

Salah satu perusahaan yang bermain pada jaringan 4G adalah BOLT. BOLT yang merupakan produk hasil dari joint venture dua perusahaan yaitu PT. Internux dan PT. First Media Tbk. BOLT Super 4G LTE (sering disebut BOLT) adalah layanan pita lebar seluler 4G Long Term Evolution pertama di Indonesia yang diluncurkan oleh Internux, pada tanggal 14 November 2013. BOLT menawarkan kecepatan akses internet hingga 150 Mbps. BOLT hanya melayani akses data, tidak dapat digunakan untuk telepon dan sms. BOLT pada awalnya dimiliki oleh Internux sejak awal peluncuran hingga tahun 2015 dan First Media mulai pertengahan tahun 2014. Tetapi mulai tanggal 1 Juli 2015, BOLT Secara resmi merupakan bagian dari First Media. Produk BOLT dibuat khusus untuk menjadi mobile wifi yaitu alat pemberi jaringan 4G tanpa kabel untuk mengakses internet pertama di Indoneisa. 4G adalah singkatan dari istilah dalam bahasa Inggris: fourth-generation technology. Istilah ini umumnya digunakan mengacu kepada standar generasi keempat dari teknologi telepon seluler. 4G merupakan pengembangan dari teknologi $3 G$ dan $2 G$. Sistem 4G menyediakan jaringan pita lebar ultra untuk berbagai perlengkapan elektronik, contohnya telpon pintar dan laptop menggunakan modem USB. BOLT memberikan kemudahan dalam mengakses internet dengan kecepatan akses yang dipercaya cukup membuat masyarakat Indonesia tertarik untuk menggunakannya.
Dengan mempelajari informasiinformasi penting untuk menciptakan pengaruh pemasaran relasional, kepercayaan dan kedekatan emosional terhadap loyalitas pelanggan, maka perusahaan dituntut untuk dapat mengembangkan pemasaran relasional, kepercayaan dan kedekatan emosional dengan pelanggan saat ini, sehingga keinginan dan persepsi pelanggan terhadap produk jasa tersebut dapat meningkat dan tetap bertahan,

\section{Tujuan penelitian}

1. Untuk mengetahui apakah pemasaran relasional, kepercayaan, dan kedekatan emosional secara bersamaan mempunya pengaruh signifikan terhadap loyalitas pelanggan di perusahaan Bolt 4G LTE ?

2. Untuk mengetahui apakah pemasaran relasional berpengaruh terhadap loyalitas pelanggan?

3. Untuk mengetahui apakah kepercayaan berpengaruh terhadap loyalitas pelanggan?

4. Untuk mengetahui apakah kedekatan emosional berpengaruh terhadap loyalitas pelanggan?

\section{TINJAUAN PUSTAKA}

\subsection{Pemasaran Relasional}

Menurut Lupiyoadi (2013) pemasaran relasional adalah suatu alternatif strategi terhadap pendekatan bauran pemasaran tradisional (yang cenderung transaksional) sebagai suatu cara memperoleh keunggulan kompetitif yang berkesinambungan (sustainable competitive advantageSCA) dan cara terbaik untuk mempertahankan pelanggan dalam jangka panjang.

Kotler dan Amstrong (2008) menyatakan pemasaran relasional (relationship marketing) adalah proses menciptakan, menjaga, dan meningkatkan hubungan yang kuat 
bernilai tinggi dengan pelanggan dan pihak yang berkepentingan.

\subsection{Kepercayaan}

Menurut Darsono (2008) Kepercayaan (trust) merupakan kesediaan (willingness) individu untuk menggantungkan dirinya pada pihak lain yang terlibat pertukaran karena individu mempunyai keyakinan (confidence) terhadap pihak lain. Sedangkan, menurut Tjiptono (2008) "Kepercayaan merupakan faktor paling krusial dalam setiap relasi”. Menurut Garbarino dan Johnson (2002) pengertian kepercayaan dalam pemasaran jasa lebih menekankan pada sikap individu yang mengacu keyakinan konsumen atas kualitas dan keandalan jasa yang diterimanya.

\subsection{Kedekatan Emosional} Menurut Barnes (2001) mengemukakan aspek yang sangat penting dari loyalitas pelanggan yang sering terlewatkan atau jarang diukur adalah hubungan emosional antara pelanggan yang loyal dengan perusahaan. Pelanggan yang memiliki loyalitas sejati memiliki merasakan ada ikatan emosional dengan perusahaan. Ikatan emosional dengan perusahaan. Ikatan emosi ini membuat pelanggan menjadi loyal dan mendorong mereka untuk tetap berbisnis dengan perusahaan itu dan membuat rekomendasi.

\subsection{Loyalitas Pelanggan}

Menurut Hasan (2008) loyalitas pelanggan (customer loyality) didefinisikan sebagai "Orang yang membeli, khususnya yang membeli secara teratur dan berulang ulang". Pelanggan merupakan seseorang yang terus menerus dan berulang kali datang ke suatu tempat yang sama untuk memuaskan keinginannya dengan memiliki suatu produk atau mendapatkan suatu jasa dan membayar produk atau jasa tersebut.

Menurut Setiawan (2014) mengungkapkan loyalitas terbentuk dari kepuasan pelanggan. Kepuasan pelanggan mampu dibentuk secara positif dan signifikan dengan menggunakan konstruk persepsi kualitas, persepsi nilai dan harapan pelanggan, dalam model struktural.

\section{METODOLOGI PENELITIAN}

Metodologi penelitian yang digunakan dalam penelitian ini adalah metode deskriptif dan metode kuantitatif.

Sumber data yang dapat diterapkan pada penelitian skripsi ini terdiri dari data primer diperoleh objek penelitian secara langsung berupa opini dari responden penelitian yang sudah melakukan pembelian ulang sebanyak lebih dari dua kali produk BOLT 4G LTE. Serta data sekunder diperoleh secara tidak langsung tentang objek yang diteliti melalui media perantara berupa website yang dimiliki oleh BOLT 4G LTE sendiri tetapi didapatkan secara tidak langsung.vMetode pengumpulan data yang dilakukan dalam penelitian ini adalah: wawancara, observasi, dan dokumentasi

Metode analisis yang digunakan peneliti adalah analisis data statistik yaitu membandingkan antara hasil riset dengan perhitungan yang dilakukan terhadap data tersebut apakah hasilnya positif dan signifikan atau malah sebaliknya.

Uji-uji yang dilakukan yaitu :

\subsection{Uji Validitas}

Uji validitas digunakan untuk mengukur sah atau valid tidaknya suatu kuesioner Ghozali (2009). Valid berarti instrumen yang digunakan dapat mengukur apa yang hendak diukur.

\subsection{Uji Reliabilitas}


Menurut Arikunto (2010) "Reliabilitas menunjukan pada satu pengertian bahwa sesuatu instrument cukup dapat dipercaya untuk dapat digunakan sebagai alat pengumpulan data karena instrumen tersebut sudah baik. Reliabilitas menunjuk pada tingkat keterendahan sesuatu".

\subsection{Uji Normalitas}

Uji normalitas adalah pengujian tentang kenormalan distribusi variabel terikat dan variabel bebas dalam model regresi. Menurut Setiawan (2013), model regresi yang baik harus memiliki distribusi data normal atau penyebaran data statistik pada sumbu diagonal dari grafik distribusi normal.

\subsection{Uji Multikolinearitas}

Uji multikolinearitas bertujuan untuk menguji apakah dalam model regresi ditemukan adanya korelasi antar variabel bebas, Ghozali (2009). Model regresi yang baik seharusnya tidak terjadi korelasi diantara variabel bebas.

\subsection{Uji Heterokedastisitas}

Uji Heteroskedastisitas bertujuan menguji apakah dalam model regresi terjadi ketidaksamaan variance dari residual satu pengamatan ke pengamatan yang lain.

\subsection{Analisis Regresi Berganda}

Analisis regresi ganda adalah alat untuk meramalkan nilai pengaruh dua variabel bebas atau lebih terhadap satu variabel terikat (untuk membuktikan ada tidaknya hubungan fungsional atau hubungan kausal antara dua atau lebih variabel bebas).

\subsection{Analisi Korelasi}

Analisis korelasi yang digunakan dalam penelitian ini adalah korelasi ganda dengan alasan karena korelasi ganda merupakan angka yang menunjukkan arah dan kuatnya hubungan antara dua variabel secara bersama-sama atau lebih dengan variabel lain. Untuk mengetahui kuat atau tidaknya hubungan antara kedua variabel, dapat dilihat dari kategori sebagai berikut:

Tabel 1. Korelasi

\begin{tabular}{|l|l|}
\hline Nilai Koefisien Korelasi & Interprestasi \\
\hline 0 & Tidak ada korelasi \\
\hline $0,01-0,20$ & Sangat lemah \\
\hline $0,21-0,40$ & Lemah \\
\hline $0,41-0,60$ & Sedang \\
\hline $0,61-0,80$ & Kuat \\
\hline $0,81-0,99$ & Sangat Kuat \\
\hline 1 & Sempurna \\
\hline
\end{tabular}

\subsection{Analisis Koefisien Determinasi}

Koefisien determinasi $\left(R^{2}\right)$ pada intinya mengukur seberapa jauh kemampuan model dalam menerangkan variasi variabel dependen, Ghozali (2009). Pedoman interprestasi koefisien determinasi menurut Riduwan (2010) dapat digambarkan pada tabel di bawah ini :

Tabel 2. Koefisien Determinasi

\begin{tabular}{|c|c|}
\hline Interval Koefisien & Tingkat Pengaruh \\
\hline $0 \%-20 \%$ & Rendah \\
\hline $21 \%-40 \%$ & Sangat Rendah \\
\hline $41 \%-60 \%$ & Sedang/Cukup \\
\hline $61 \%-80 \%$ & Tinggi \\
\hline $81 \%-100 \%$ & Sangat Tinggi \\
\hline
\end{tabular}

(sumber : Setiawan, 2015)

\section{HASIL DAN PEMBAHASAN}

\subsection{Pemasaran Relasional, Kepercayaan, Kedekatan Emosional secara bersama-sama berpengaruh terhadap loyalitas pelanggan \\ Dalam penelitian menunjukan} hubungan antara pemasaran relasional, kepercayaan, kedekatan emosional dapat diterima, hal ini ditunjukan dengan nilai fhitung sebesar 715,950 yang dimana lebih besar dari f-tabel 105,573. Yang dimana veriabel-variabel tersebut berpengaruh signifikan terhadap loyalitas pelanggan yang telah diolah oleh SPSS. 


\subsection{Pemasaran Relasional berpengaruh terhadap Loyalitas Pelanggan}

Dalam penelitian menunjukan hubungan antara pemasaran relasional terhadap loyalitas pelanggan dapat diterima, hal ini ditunjukan dengan nilai thitung sebesar 2,746 yang dimana lebih besar dibandingkan t-tabel 1.66 dan didukung oleh nilai signifikansi 0.000 lebih kecil dibandingkan dengan 0.05 yang dimana variabel tersebut berpengaruh signifikan terhadap loyalitas pelanggan yang telah diolah oleh SPSS.

BOLT harus menerapkan dan mempelajari pemasaran relasional dalam perusahaannya agar dapat berkembang dan lebih maju lagi untuk memenuhi kebutuhan para konsumennya. Maka, Manager yang ada di BOLT harus meningkatkan pemasaran relasional dalam perusahaannya agar perusahaan mendapatkan hubungan yang lebih dekat dengan pelanggan. Yang menyatakan pemasaran relasional berpengaruh secara positif dan signifikan terhadap loyalitas penelitian, penelitian ini membuktikan teori yang disampaikan oleh Kotler dan Amstrong (2008) menyatakan pemasaran relasional (relationship marketing) adalah proses menciptakan, menjaga, dan meningkatkan hubungan yang kuat bernilai tinggi dengan pelanggan dan pihak yang berkepentingan.

\subsection{Kepercayaan Berpengaruh terhadap Loyalitas Pelanggan}

Dalam penelitian menunjukan hubungan antara kepercayaan terhadap loyalitas pelanggan dapat diterima, hal ini ditunjukan dengan nilai t-hitung sebesar 2,045 yang dimana lebih besar dibandingkan t-tabel 1.66 dan didukung oleh nilai signifikansi 0.000 lebih kecil dibandingkan dengan 0.05 yang dimana variabel tersebut berpengaruh signifikan terhadap loyalitas pelanggan yang telah diolah oleh SPSS.

Apabila, kepercayaan dari konsumen didapatkan oleh perusahaan dengan baik pastinya perusahaan akan berkembang baik dan mendapatkan loyalitas dari konsumen yang memang menjadi tujuannya.

Menurut Tjiptono

"Kepercayaan merupakan faktor paling krusial dalam setiap relasi”. Menurut Garbarino dan Johnson (2002) pengertian kepercayaan dalam pemasaran jasa lebih menekankan pada sikap individu yang mengacu keyakinan konsumen atas kualitas dan keandalan jasa yang diterimanya.

\subsection{Kedekatan Emosional berpengaruh terhadap Loyalitas pelanggan \\ Dalam penelitian menunjukan} hubungan antara kedekatan emosional terhadap loyalitas pelanggan tidak dapat diterima, hal ini ditunjukan dengan nilai thitung sebesar 3.244 yang dimana lebih kecil dibandingkan t-tabel 1.66 dan didukung oleh nilai signifikansi 0.000 lebih besar dibandingkan dengan 0.05 yang dimana variabel tersebut tidak signifikan terhadap loyalitas pelanggan yang telah diolah oleh SPSS .

Dinyatakan oleh Barnes (2001) mengemukakan aspek yang sangat penting dari loyalitas pelanggan yang sering terlewatkan atau jarang diukur adalah hubungan emosional antara pelanggan yang loyal dengan perusahaan. Pelanggan yang memiliki loyalitas sejati memiliki merasakan ada ikatan emosional dengan perusahaan. Ikatan emosional dengan perusahaan. Ikatan emosi ini membuat pelanggan menjadi loyal dan mendorong mereka untuk tetap berbisnis dengan perusahaan itu dan membuat rekomendasi.

Untuk alasan inilah penting bagi perusahaan untuk memusatkan perhatian pada bagaimana mereka memperlakukan pelanggan dan bagaimana menumbuhkan perasaabn positif dalam diri pelanggan. Menciptakan emosi dan perasaan positif sangat penting dalam membangun hubungan. Ketiadaan emosi tersebut membuat pembelian yang berulang menjadi sebuah aktifitas mekanis, proses perilaku, membuat pelanggan tidak memiliki alasan yang nyata untuk tinggal. 
Loyalitas pelanggan sejati tidak mungkin tercipta tanpa adanya hubungan emosional. Loyalitas adalah bukti dari emosi yang mentransformasikan perilaku pembelian berulang menjadi sebuah hubungan. Jika pelanggan tidak merasakan adanya kecintaan atau kedekatan pada penyedia jasa atau organisasi lain, maka hubungan antara pelanggan dan perusahaan tidak memiliki karakteristik suatu hubungan, pelanggan itu sendiri mengetahui dan mampu mengatakan, adanya keterikatan emosi antara mereka dengan individu penyedia jasa.

Hubungan adalah suatu hal yang sangat rumit dan perlu dikelola secara hatihati dan membutuhkan keahlian dari orangorang yang terlibat hubungan juga diistilahkan sebagai proses yang amat rumit dan panjang dengan banyak jebakan dan tantangan. Hubungan tidak begitu saja terjadi itu harus dimulai, dilaksanakan, dikembangkan, dan dijaga agar tetap berlangsung baik. Salah satu keistimewaan yang menarik dari hubungan adalah bahwa hubungan adalah suatu proses yang terus menerus..

\section{KESIMPULAN}

1. Hasil analisis diperoleh bahwa variabel pemasaran relasional (X1), kepercayaan (X2), kedekatan emosional (X3) secara bersama-sama mempunyai pengaruh yang positif dan signifikan terhadap loyalitas pelanggan (Y). Dengan demikian hipotesis 1 yang menyatakan bahwa pemasaran relasional (X1), kepercayaan (X2), kedekatan emosional (X3) berpengaruh positif terhadap loyalitas pelanggan $(Y)$ dapat diterima

2. Hasil analisis diperoleh bahwa variabel pemasaran relasional (X1) memiliki koefisien regresi sebesar 0,187 (bertanda positif) terhadap loyalitas pelanggan $(Y)$ dan nilai thitung sebesar 2,746 , dengan tingkat signifikansi 0,000 (< 0.05). Hal ini berarti bahwa pemasaran relasional (X1) berpengaruh positif terhadap loyalitas pelanggan $(\mathrm{Y})$. Dengan demikian Hipotesis 2 yang menyatakan bahwa pemasaran relasional $(\mathrm{X} 1)$ berpengaruh positif terhadap loyalitas pelanggan $(\mathrm{Y})$ dapat diterima.

3. Hasil analisis diperoleh bahwa variabel kepercayaan (X2) memiliki koefisien regresi sebesar 0,211 (bertanda positif) terhadap loyalitas pelanggan $(Y)$ dan nilai thitung sebesar 2,045 dengan tingkat signifikansi $0,000(<0.05)$. Hal ini berarti bahwa kepercayaan (X2) berpengaruh positif terhadap loyalitas pelanggan ( $\mathrm{Y}$ ). Dengan demikian Hipotesis 3 yang menyatakan bahwa kepercayaan (X2) berpengaruh positif terhadap loyalitas pelanggan $(Y)$ dapat diterima.

4. Hasil analisis diperoleh bahwa kedekatan emosional (X3) memiliki koefisien regresi sebesar 0,357 (bertanda positif) terhadap loyalitas pelanggan $(\mathrm{Y})$ dan nilai thitung sebesar 3,244 dengan tingkat signifikansi $0,000(<0.05)$. Hal ini berarti bahwa kedekatan emosional (X3) berpengaruh positif terhadap loyalitas pelanggan (Y). Dengan demikian Hipotesis 4 yang menyatakan bahwa kedekatan emosional (X3) berpengaruh positif terhadap loyalitas pelanggan $(Y)$ dapat diterima.

5. Nilai Adjusted $R$ square diperoleh sebesar 0,760 . Hal ini berarti bahwa $76 \%$ loyalitas pelanggan ( $\mathrm{Y}$ ) dapat dijelaskan oleh variabel pemasaran relasional (X1), kepercayaan (X2), dan kedekatan emosional (X3). Sedangkan 24\% dapat dijelaskan oleh sebab-sebab lain yang tidak diteliti dalam penelitian ini.

\section{SARAN}

1. Berdasarkan hasil jawaban responden pada variabel pemasaran relasional dapat diketahui bahwa nilai rata-rata yang paling kecil adalah pernyataan 5 $(56,4 \%)$ yaitu BOLT memberikan kompensasi atas pelayanan yang tidak sesuai kepada saya. Maka dari itu perusahaan harus lebih memperhatikan pelayanan mereka dan memberikan kompensasi yang sesuai kepada 
pelanggan agar terjaganya hubungan yang baik dengan pelanggan.

2. Berdasarkan hasil jawaban responden pada variabel kepercayaan dapat diketahui bahwa nilai rata-rata yang paling kecil adalah pernyataan 3 $(63,4 \%)$ yaitu BOLT melakukan dengan cepat penanganan keluhan. Maka dari itu perusahaan harus menekankan dan meningkatkan pelayanan mereka dalam penanganan keluhan pelanggan sehinggan konsumen merasa percaya kepada perusahaan karena mempunyai komitmen yang tinggi terhadap pelanggan.

3. Berdasarkan hasil jawaban responden pada variabel kedekatan emosional dapat diketahui bahwa nilai rata-rata yang paling kecil adalah pernyataan 2 $(64,8 \%)$ yaitu kedekatan pelanggan dengan pihak perusahaan BOLT terjalin dengan baik, dengan pelayanan yang ramah dan setulus hati. Maka dari itu perusahaan harus meningkatkan Kedekatan dengan pelanggan, dalam kaitannya keramahan karyawan, sikap karyawan saat pelanggan datang, mengawali pelayanan selama melayani, hingga mengakhiri pelayanan. Hal ini diharapkan agar terjadi hubungan timbal balik dengan pelanggan supaya pelanggan tidak ragu-ragu untuk mengemukakan keluhannya.

4. Berdasarkan hasil jawaban responden pada variabel loyalitas pelanggan dapat diketahui bahwa nilai rata-rata yang paling kecil adalah pernyataan 2 $(45,2 \%)$ yaitu BOLT merupakan pilihan pertama saya dalam akses jaringan. Maka dari itu perusahaan harus meningkatkan loyalitas pelanggan agar pelanggan merasa puas dengan kinerja perusahaan dan tidak berpindah ke produk lain.

\section{DAFTAR PUSTAKA}

Chan. 2008. Relastionship Marketing Inovasi Pemasaran yang Membuat Pelanggan Bertekuk Lutut. PT. Gramedia Pustaka Utama. Jakarta.

Darmawan, Rizky. 2017. "Pengaruh Kualitas Pelayanan, Harga dan Kepercayaan Terhadap Keputusan Pembelian (Studi Kasus Lazzada.co.id)". Skripsi.

Darsono, 2008. Hubungan Perceived Service Quality dan Loyalitas: Peran Trust dan Satisfaction sebagai Mediator, The 2 nd National Conference UKWMS, Surabaya

Ellena Frieda. 2011. "Analisis Pengaruh Kepercayaan, Komitmen, Komunikasi, dan Penanganan Keluhan Terhadap Loyalitas Nasabah". Universitas Diponegoro. Semarang.

Farida, Ida. 2015, "Hubungan Dimensi Pemasaran Relational Terhadap Loyalitas Nasabah pada PT Asuransi Takaful Keluarga Cabang Bintaro". Universitas Islam Negeri. Jakarta.

Hasan, Ali. 2008. Marketing. Media Utama, Yogyakarta.

Hurryati, Ratih, 2010, Bauran Pemasaran dan Loyalitas Konsumen,cetakan keempat; Bandung: ALFABETA.

Kotler, Philip; Armstrong, Garry, 2008. Prinsipprinsip Pemasaran, Jilid 1, Erlangga, Jakarta.

Lupiyoadi, Rambat, 2013, Manajemen Pemasaran Jasa, Edisi ketiga, Penerbit Salemba Empat, Jakarta.

Monika, Dinda. 2010, "Analisis Pengaruh Nilai Pelanggan, Kualitas Pelayanan dan Kedekatan Emosional Terhadap Loyalitas Nasabah (Studi kasus pada Bank BRI cabang pattimura Semarang)". Universitas Diponegoro. Semarang.

Munandar, Dadang. 2016. Relationships Marketing : Strategi Menciptakan Keunggulan Bersaing. EKUILIBRIA, Yogyakarta.

Nuhung, Mahmud. 2011. "Studi Kualitas Jasa dan Pemasaran Relasional, Pengaruhnya Terhadap Kepuasan dan Loyalitas Nasabah Bank Syariah Di Kota Makasar". Jurnal Ekonomi Balance Vol.7.

Pamariadinata, Frieska. 2008, "Analisis Pengaruh Kepuasan Pelanggan dan Hubungan Emosional Terhadap Loyalitas Pelanggan (studi kasus pada radio Trax fm Semarang)", Universitas Diponegoro, Semarang. 
Riana, Gede. 2008. "Pengaruh trust in a brand terhadap brand loyalty pada konsumen air minum aqua di kota denpasar". Buletin studi ekonomi, Vol. 13, No. 2, 2008, hal. 184-202.

Saladin, Djaslim. 2007. Intisari Pemasaran dan Unsur - Unsur Pemasaran. Bandung : Linda Karya.

Sandri, Mita. 2013. "Pemasaran Relasional dan Kualitas Pelayanan Pengaruhnya Terhadap Loyalitas Pelanggan di Matahari Department Store Manado". Vol.3. Universitas Sam Ratulangi. Manado.

Setiawan, B. (2013). Menganalisa statistik bisnis dan ekonomi dengan SPSS 21. Yogjakarta, Andi Yogyakarta.

Setiawan, B. (2014). Customer Satisfaction Index Model on Three Level Of Socioeconomic Status In Bogor Case Study: Customer Satisfaction on Branded Cooking Oil Product. ASEAN Marketing Journal, 6(1).

Setiawan, Budi. 2015. Teknik Praktis Analisis Data Penelitian Sosial \& Bisnis dengan SPSS. Yogyakarta: ANDI.

Silmi, Suhilda. 2012, "Persepsi Nasabah Tentang Relationship Marketing dan Pengaruhnya Terhadap Loyalitas (studi pada nasabah tabungan utama PT. Bank Mega Syariah cabang malang)". Universitas Negeri Malang.

Sugiyono. 2012. Memahami penelitian kuantitatif. Bandung: ALFABETA.

Supardi, Yuniar. 2009. Internet Untuk Segala Kebutuhan. PT Elex Media Komputindo. Jakarta.

Tjiptono, Fandy. 2008. Service Management. Yogyakarta : Andi.

Umi Narimawati. 2010. Penulisan Karya Ilmiah. Jakarta: Penerbit Genesis.

Usman, Husaini, 2013, Manajemen (Teori, praktik, dan Riset Pendidikan), Edisi Keempat, penerbit Bumi Aksara.

West, Ford \& Ibrahim. 2010. Strategic Marketing : Creating Competitive Advantage. 2nd. Oxford University Press.

Widyastuti Yanita. 2014. "Analisis Relationalship Marketing Terhadap Loyalitas Pelanggan". Sekolah Tinggi Ilmu Ekonomi Indonesia. Surabaya.

http://www.pengertianmenurutparaahli.net/peng ertian-pelanggan-menurut-para-ahli/. 